\title{
Current International Legal Issues: Bangladesh
}

\author{
Muhammad Ekramul Haque*
}

\section{Introduction}

Bangladesh is presently an active participant in the international legal system, in large part due to its emerging economy based on ready made garments ${ }^{1}$ exports and its near graduation ${ }^{2}$ from Least Developed Country (LDC) category towards becoming a middle-income country. The development story of Bangladesh ${ }^{3}$ represents a successful turn from being a 'basket' case with improvements in various indices and measures of international development regime, more particularly the Millennium Development Goals (MDGs) and subsequent Sustainable Development Goals (SDGs). However, being one of the most vulnerable nations affected by climate change, ${ }^{4}$ it also is an active advocate of various international measures on environmental issues. The recent refugee influx of Rohingyas from Myanmar also puts the country in focus, particularly in areas of refugee rights and their right to return. The geographic position of Bangladesh as a littoral state with exceptional coastlines also led to amicable litigation with neighbouring India and Myanmar, with the judgments and awards contributing to international maritime jurisprudence. ${ }^{5}$

* Professor, Department of Law, University of Dhaka, Bangladesh.

1 Kaushik Basu, Why is Bangladesh Booming?, The Daily Star (Apr. 27, 2018, 12:00 AM), https://www.thedailystar.net/opinion/project-syndicate/why-bangladesh-booming-1568233.

2 Debapriya Bhattacharya \& Sarah Sabin Khan, Bangladesh's Graduation from the LDC Group: Pitfalls and Promises: Clarifying the MIC-LDC Confusion, The DAILY StAR (Mar. 21, 2018, 12:00 AM), https://www.thedailystar.net/opinion/economics/clarifying-the-mic-ldcconfusion-1550980.

3 See Oxford Union, Bangladesh Panel Discussion: Full Discussion and Q\&A, YouTube (June 19, 2016), https://www.youtube.com/watch?v=wBvıXhkeS_o (discussing the development of Bangladesh from a basket case to a global model of development; some prominent figures like Dr. Kamal Hossain, Dr. Gowher Rizvi, Professor Sir Paul Collier and Professor Nathan MCube took part in this discussion).

4 See David Eckstein et al., Global Climate Risk IndeX 2019, Germanwatch (2018), https://www.germanwatch.org/sites/germanwatch.org/files/Global\%2oClimate\%2o Risk\%2oIndex\%202019_2.pdf (showing that Bangladesh has ranked 7th in the list of most affected countries of climate change in the world in the Global Climate Risk Index 2019).

5 See Abdullah Al Faruque, Judgment in Maritime Boundary Dispute Between Bangladesh and Myanmar: Significance and Implications Under International Law, 18 AsIAN YeARBooк OF International LaW 64 (2012); see also D. H. Anderson, Delimitation of the Maritime Boundary in the Bay of Bengal (Bangladesh/Myanmar), 106 AMERICAN Journal OF INTERNATIONAL LAW 817 (2012). 
Additionally, Bangladesh also spearheads various regional cooperation initiatives such as the South Asian Association for Regional Cooperation (SAARC) and the Bay of Bengal Initiative for Multi-Sectoral Technical and Economic Cooperation (BIMSTEC). These factors contributed to the country becoming increasingly immersed in international legal issues. In the past, the unique birth of Bangladesh as a new state in 1971 through a war against Pakistan invoked international legal concepts such as the people's right to self-determination ${ }^{6}$ in a setting that was not colonial in the traditional sense, and as well raised issues of recognition and state succession, putting the relevant international legal rules in a new perspective. ${ }^{7}$ Moreover, the genocide and other international crimes that occurred during the war of 1971 represent some issues that are yet to be resolved, particularly regarding the foreign perpetrators, with Bangladesh setting up domestic international crimes' courts for trial of some local offenders and collaborators. International law has become more relevant to Bangladesh as it becomes more embedded in the global economy, particularly in areas of international trade, environment, and labour rights. Furthermore, the apex judiciary of Bangladesh commendably frequently relies on the international human rights regime to expand the protection of fundamental rights granted by the Constitution of Bangladesh, particularly in areas such as protection of women and children, protection of environment, and ensuring the right to life and liberty. 8

\section{Refugee Law and the Rohingya Crisis}

In connection with the age-old persecution carried out in Myanmar against its Rohingya minority, ${ }^{9}$ a recent refugee crisis was encountered by Bangladesh. The Rohingya people who are historically claimed by Myanmar as Bangladeshbred fled from Myanmar and as a result, the host State, Bangladesh experienced

6 See M. Rafiqul Islam, Secessionist Self-Determination: Some Lessons from Katanga, Biafra and Bangladesh, 22 Journal of Peace Research 211 (1985).

7 For details of the international legal implications of the liberation war of 1971, see M. RAFIQUL Islam, The BANGLADESh Liberation Movement: International Legal IMPliCATIONS (1st ed. 1987).

8 E.g., II ADC (2005) 371; Bangl. v. Hasina, 6o DLR (AD) (2008) 90.

9 See Md Jobair Alam, The Rohingya Minority of Myanmar: Surveying Their Status and Protection in International Law, 25 International Journal on Minority \& Group Rights 157 (2018); see also Jobair Alam, The Rohingya of Myanmar: Theoretical Significance of the Minority Status, 19 Asian ETHNICITY 180 (2018) (describing a critical examination of the Rohingya minority crisis in international law). 
and witnessed one of the largest influxes of migrant refugees of this region. The Rakhine Population, resident in the Rakhine Province of Myanmar, more widely known as Rohingya, have throughout the years been considered as one of the most unwanted accumulations of people. ${ }^{10}$ Huge amounts of people, amassing to hundreds of thousands have fled into Bangladesh to escape violence. Statistically speaking, approximately 700,000 Rohingya have fled over international borders into Bangladesh by mid-August 2018, following an operation. This very recent instance is not sole in nature. Such an incident has happened before in the past, looking back to 1978, 1992 and 1996, where these Rohingya people had made their way into Bangladesh. An estimated one million Rohingya reside in Bangladesh. These incidents of exoduses have brought up the question of what these people can be referred to from the point of view of International Law, and this has sparked debates over their status as refugees. ${ }^{11}$

One of the pivotal reasons of such a question arising is the fact that Bangladesh is not a party to the 1951 Convention on Refugee. However, this fact does not necessarily free Bangladesh from all responsibilities regarding Rohingya, taking into consideration the fact that Bangladesh is a party to several other International Treaties which include the International Covenant on Civil and Political Rights (ICCPR) and the United Nations Convention on Cruel, Inhuman and Degrading Treatment and Punishment (САT). Bangladesh has, in compliance with its customary international obligation of non-refoulement, accepted the Rohingya population into its territory. Non-refoulement principle has bound the country despite its being a non-signatory to the Convention by dint of the character that the principle has attained beyond treaties and conventions. Even though not under the United Nations High Commissioner for Refugees (UNHCR) Convention, non-refoulement is an obligation for the country to comply with under international instruments such as the Universal Declaration of Human Rights, ICCPR and CAT. The status determination was (as it happens in the context of South Asia and other developing countries) a prima facie group status determination.

10 See Archana Parashar \& Jobair Alam, The National Laws of Myanmar: Making of Statelessness for the Rohingya, 57 INTERNATIONAL Migration 94 (2019) (critically analysing the current status of the Rohingya people); see Nehginpao Kipgen, The Rohingya Crisis: The Centrality of Identity and Citizenship, 39 Journal of Muslim Minority Affairs 61 (2019) (demonstrating the Myanmar government's showing its unwillingness to address the issue of ethnicity, nationality and citizenship).

11 It is to be noted that the host country Bangladesh is not 'officially' calling the Rohingya people as 'refugee.' 
The Human Rights Committee in its Concluding Observations on the initial report submitted by Bangladesh as a state party to the ICCPR expressed its concern over the issue of large number of 'refugees' in Bangladesh and observed: 'The State party [to the ICCPR] should implement legislative and administrative measures to fully comply with the principle of non-refoulement in line with articles 6 and 7 of the Covenant [ICCPR]. It should consider acceding to the 1951 Convention relating to the Status of Refugees and its 1967 Protocol. It should ensure that refugees are not forcibly relocated and that planned relocation sites offer conditions of life compatible with the international obligations of the State party.'12 The Committee on Economic, Social and Cultural Rights (CESCR) in its Concluding Observations on the initial report submitted by Bangladesh as a state party to the ICCPR appreciated Bangladesh 'for the efforts of the State party to host over a million Rohingya refugees forced to flee systematic and violent persecution, and recognizes the immense challenges faced by the State party as host country'13 The CESCR expressed its deep concern 'that these Rohingya do not have legal status in the State party, which restricts their movement outside of the camps to access health-care services, education and other basic services' 14 and has made the following recommendation:

The Committee recommends that the State party take effective measures to recognize the legal status of the Rohingya, with a view to ensuring their access to livelihoods, health care, particularly emergency medical treatment, education and other basic services provided outside of the camps. ${ }^{15}$ It also recommends that the State party, with the humanitarian assistance of the international community, take immediate measures to ensure the safety of the Rohingya in camps and to safeguard against outbreaks of diseases such as diphtheria and cholera. Welcoming the launch of the 2018 joint response plan for the Rohingya humanitarian crisis, the Committee encourages the State party to continue its efforts to seek international assistance and cooperation in improving the living conditions of the Rohingya, and in seeking durable solutions to their situation. ${ }^{16}$

12 UN Human Rights Comm., Concluding Observations on the Initial Report of Bangladesh, U.N. Doc. CCPR/C/BGD/CO/1 (Apr. 27, 2017), https://www.refworld.org/docid/591e97c54 .html.

13 UN Econ. and Soc. Council (CESCR), Concluding Observations on the Initial Report of Bangladesh, U.N. Doc. E/C.12/BGD/CO/1 (Apr. 18, 2018), https://tbinternet.ohchr.org/_layouts/ treatybodyexternal/Download.aspx?symbolno=E/C.12/BGD/CO/1\&Lang=En.

$14 \quad$ Id.

$15 \quad I d$.

$16 \quad I d$. 
UNHCR has started advocating for repatriation of the Rohingya refugees back to Myanmar; however, the concern lies with the fact that the repatriation might not be a voluntary one as has been envisaged by the international refugee instruments in order to supposedly constitute the 'end' to a refugee cycle. The repatriation that was facilitated by UNHCR in 1992 was widely thought to be tainted with an essentially 'non-voluntary' character which never led to a successful reintegration of the repatriated Rohingya people in Myanmar, and rather paved the way for further problems.

However, recently the Prosecutor of the International Criminal Court (ICC) requested the Pre-Trial Chamber of ICC under Article 19(3) of the ICC Statute to adjudge whether the ICC has jurisdiction 'over the alleged deportation of members of the Rohingya people from the Republic of the Union of Myanmar ("Myanmar") to the People's Republic of Bangladesh ("Bangladesh").17 The main difficulty the Pre-Trial Chamber had to face was the issue of the applicability of the ICC Statute to Myanmar who is not a state party to the Statute. The Pre-Trial Chamber, applying the principle of la competence de la competence or Kompetenz-Kompetenz, a well-established principle of international law according to which a tribunal can determine its own extent of jurisdiction, exercised its jurisdiction to determine its own jurisdiction. The Chamber reasoned that since an element of crime (crossing of a border) occurred on the territory of Bangladesh (which is a state party to the Statute), the Court may exercise its jurisdiction to prosecute the crime. ${ }^{18}$ However, the government of Myanmar rejected the ruling of the Pre-Trial Chamber and called the ruling a result of faulty procedure and dubious merit on the basis that Myanmar is not a state party to ICC Statute and therefore the country is not under any obligation to respect the decision of the ICc. However, international commentators have seen the decision as a 'step forward for stopping forced deportations.' ${ }^{19}$

17 Decision on the "Prosecution's Request for a Ruling on Jurisdiction under Article 19(3) of the Statute", ICC-RoC46(3)-01/18-37, ๆ1 (Sept. 6, 2018), https://www.icc-cpi.int/Court Records/CR2018_04203.PDF.

18 It is to be noted that there was a dissenting opinion from Judge Perrin de Brichambaut on the procedural grounds. Judge Perrin reasoned that the ruling requested by the Prosecutor shall amount to an advisory opinion, which the Court is not empowered to do.

19 See Victoria Colvin \& Phil Orchard, The Rohingya Jurisdiction Decision: A Step Forward for Stopping Forced Deportations, 73 Australian Journal of International Affairs 16 (2019); see Morten B. Pedersen, The ICC, the Rohingya and the Limitations of Retributive Justice, 73 Australian Journal of International Affairs 9 (2019); see also Douglas Guilfoyle, The ICC Pre-Trial Chamber Decision on Jurisdiction over the Situation in Myanmar, 73 Australian Journal of International Affairs 2 (2019). 
With a view to trying the accused persons of war crimes, in the liberation war of Bangladesh in 1971, the International Crimes Tribunal Act was enacted in 1973, only two years after the independence. ${ }^{20}$ However, due to multifarious issues intertwined between domestic and international politics, ${ }^{21}$ the trials took a substantial period of time to in fact begin. In 2009, a significant number of amendments were brought to the Act. ${ }^{22}$ The suspects were identified by the War Crimes Fact Finding Committee prior to the formation of the Tribunal. Under the Act, the first tribunal was established and in 2010, the first few indictments were issued. A second tribunal was constituted in March 2012 in order to speed up the war crimes trials. As of 2015, only one tribunal is in place; the second one established in 2012 became a non-functioning one following a decrease in the number of cases.

In accordance with its title, this law is 'an Act to provide detention, prosecution, and punishment of persons for genocide, crimes against humanity, war crimes, and other crimes under international law'. ${ }^{23}$ The Crimes Tribunal prosecutes offences that share a particular commonality in terms of their substantive definitions appearing within the rubric of international instruments and the domestic piece of legislation in particular. However, in terms of the elements of crimes, there is quite a distinct line differentiating the two streams. One reason that can be said to have been behind such anomaly is the fact that the nature of crimes that were committed in 1971, required such an approach. The crimes were committed by civilians from the Eastern wing of the then Pakistan, who formed Peace (Shanti) Committee and Razakar, Al Badr, Al Shams Bahini 'auxiliary forces', and led those in aiding and collaborating with the Pakistani occupation army in committing the systemic crimes constituting

20 See A. K. M. Saiful Islam, Why War Crimes Tribunals Are Important for Bangladesh, THE HILL (Dec. 20, 2013, 04:00 PM), https://thehill.com/blogs/congress-blog/foreign-policy/ 193696-why-war-crimes-tribunals-are-important-for-bangladesh.

See M. Rafiqul Islam, War Crimes Trial: Shimla Pact Not a Legal Barrier, The DAILY StAR (Mar. 20, 2010), https://www.thedailystar.net/law/2010/03/03/index.htm (discussing how it was initially thought that Shimla Pact was a legal barrier to the trial of international crimes in Bangladesh. However, Professor M. Rafiqul Islam showed why it was not a barrier at all).

22 International Crimes (Tribunals) (Amendment) Act 2009 (Bangl.), http://www.parliament .gov.bd/index.php/en/parliamentary-business-3/business-of-the-house/bill-and-leg islation/acts-of-parliament/acts-of-parliament-gth-parliament/acts-of-2nd-session/ 1772-23-the-international-crimes-tribunals-amendment-act-2009.

23 International Crimes (Tribunals) Act 1973, Preamble, https://ihl-databases.icrc.org/ applic/ihl/ihl-nat.nsf/o/o618daaa266oegb3c125771aoo264b13/\$FILE/International\% 2oCrimes\%2o(Tribunals)\%2oAct,\%201973\%2o(as\%2oamended\%20in\%202009).pdf. 
offences such as abduction, confinement, torture, murder and other inhuman acts, as crimes against humanity and war crimes. Thus, the nature of crimes was essentially different from that of the ones whose trial international criminal law envisages. The tribunals constituted under this Act are forums of first instance, appeals against whose decisions lie with the Appellate Division of the Supreme Court. This Act is not an enabling legislation for implementing the international obligations of Bangladesh under international humanitarian law, rather it is specifically dedicated to the trial of the offenders of 1971. Till August 2018, the Tribunals have delivered judgments in 34 cases against 83 criminals of war crimes. Among the accused persons, $5^{2}$ were sentenced to death. After thirty-nine years of independence, the initiative taken by the State to try the accused of war crimes is laudable; however, it is of interest to note that internationally, certain human rights organizations raised some questions regarding the standard of these trial proceedings. ${ }^{24}$

\section{$4 \quad$ Law of the Sea and the Settlement of Maritime Boundaries Disputes with Myanmar and India}

The maritime dispute between Myanmar and Bangladesh concerned the delimitation of the territorial sea, exclusive economic zones and continental shelves of these two States. ${ }^{25}$ The maritime boundary dispute with Myanmar was settled by the International Tribunal for the Law of the Sea (ITLOS) in the Dispute Concerning Delimitation of the Maritime Boundary Between Bangladesh and Myanmar in the Bay of Bengal (Bangladesh/Myanmar) (Case No. 16, Judgment pronounced on 14 March 2012), which has been a milestone judgment in the history of the law of the sea. ${ }^{26}$

24 For critique of the trial proceedings, see Surabhi Chopra, The International Crimes Tribunals in Bangladesh: Silencing Fair Comment, 17 JournaL of GeNOCIDE RESEARCH 211 (2015); Muhammad Abdullah Fazi et al., A Legal Analysis of the International Crimes Tribunal Bangladesh: A Fair Trial Perspective, 2 The Asian YeArbook of Human Rig hts \& HUMANITARIAN LAW $35^{\circ}$ (2018). For a reply to the criticisms against the trial proceedings, see M. Rafiqul Islam, War Crimes Trial and International Standard, THE DAILY STAR (Feb. 19, 2011), https://www.thedailystar.net/law/2011/02/03/index.htm.

25 Dispute Concerning Delimitation of the Maritime Boundary Between Bangladesh and Myanmar in the Bay of Bengal (Bangl./Myan.), Case No. 16, Judgment of Mar. 14, 2012, ITLOS Rep. 4.

26 For an analytical discussion on the reason of preferring to settle the maritime dispute in an international organization rather than by bilateral negotiation, see Kyawt Kyawt Khine, Maritime Boundary Dispute Between Myanmar and Bangladesh, 6 Mandalay UnIVERSity Research Journal 37 (2015); see also Aniruddha Rajput, Bay of Bengal Maritime Delimitation Cases: Upholding the Rule of Law in International Relations, 14 MARITIME 
While delimiting the territorial sea, the Tribunal drew an equidistance line from the baselines which were drawn by the respective States in accordance with Article 15 of the 1982 Convention on the Law of the Sea (1982 Convention). ${ }^{27}$ The Tribunal was of the opinion that there were no special circumstances (St. Martin's Island which was argued by Myanmar to constitute a special circumstance was not found by the tribunal to do so), which could render deviation from the equidistance line.

In respect of the delimitation of the exclusive economic zones and the continental shelves, the Tribunal came to the finding that in light of Articles 74 and 82 of the 1982 Convention, in order to achieve an equitable result, it was required to draw a single maritime boundary. A provisional equidistance line was initially decided to be drawn by the Tribunal; however, taking into consideration the concavity of Bangladesh coast, the said provisional equidistance line was adjusted. Through the Myanmar judgment, Bangladesh obtained the declaration of its sovereign right to a 200 nautical mile exclusive economic zone and to a substantial share of the outer continental shelf beyond 200 nautical miles. The judgment was welcomed by both the states and was regarded as a win-win case. ${ }^{28}$

Following the resolution of the maritime boundary dispute between Myanmar and Bangladesh through the judgment rendered by the Tribunal, came the resolution of the long-drawn maritime dispute between India and Bangladesh. ${ }^{29}$ This dispute was decided by an arbitral tribunal administered by the Permanent Court of Arbitration (PCA) situated at The Hague. In delimiting the territorial sea between Bangladesh and India, the PCA decided to apply the equidistant methodology; but it then noted that the land boundary terminus (determined by reference to a previous Radcliffe Award) needed to be considered as a 'special circumstance', making a strict application of the equidistance methodology inequitable. In deciding upon the delimitation of the exclusive

Affairs: Journal of the National Maritime Foundation of India 24 (2018) (viewing the settlement of maritime dispute of Myanmar, Bangladesh and India through binding dispute resolution mechanism under the UNCLOs as a ray of hope of establishment of international rule of law).

27 For a commentary on such decision, see Faruque, supra note 5, at 69.

28 See Ravi A. Balaram, Case Study: The Myanmar and Bangladesh Maritime Boundary Dispute in the Bay of Bengal and Its Implications for South China Sea Claims, 31 JourNAL OF Current Southeast Asian Affairs 85 (2012) (finding the Rohingya crisis as an implication of this decision).

29 See Marcin Kaldunski, A Commentary on the Maritime Boundary Arbitration Between Bangladesh and India Concerning the Bay of Bengal, 28 LEIDEN Journal of INTERNATIONAL LAW 799 (2015) (commenting on the award of the Tribunal from the viewpoint of law of maritime delimitation). 
economic zones and the continental shelves, however, the equidistance/ relevant circumstances rule was found to be the most preferable. A very interesting thing to note is that at the end of both of these cases, all the contending parties claimed a 'victory' from their respective positions.

One important aspect of these two cases is their resulting effect of the formation of a 'Grey Area' in the northern Bay of Bengal. It involves the intersection and overlap of rights and responsibilities in the exclusive economic zone and continental shelf regime. ${ }^{30}$

Bangladesh is a party to the United Nations Convention on the Law of the Sea (UNCLOS), 1982. The Constitution of Bangladesh by its article 143 empowered the Parliament to make necessary laws regarding the delimitation of maritime boundaries of Bangladesh. Bangladesh enacted a law regarding maritime boundaries and other ancillary matters in 1974, which is called the Territorial Waters and Maritime Zones Act. Considering the fact that the law is inadequate and has been outdated, the making of a new legislation is now in the process. The Bangladesh Maritime Zones Act, 2018 (Draft Law) is a comprehensive law comparing it to the 1974 Act. The proposed law includes certain specific objectives to attain. ${ }^{31}$ They are: 'to provide for the declaration and determination of the maritime zones and to provide for the suppression of piracy, armed robbery, theft and to make provisions for punishment and for matters connected therewith; the determination of the boundaries of the territory of Bangladesh and of the territorial seas and the continental shelf of Bangladesh; ${ }^{32}$ to determine maritime boundaries of territorial sea, internal waters, continental shelf, contiguous zone and Exclusive Economic Zone between Bangladesh and its neighbouring coastal States in the territorial sea in accordance with the 14 March 2012 Judgment of the International Tribunal for the Law of the Sea in the Dispute Concerning Delimitation of the Maritime Boundary Between Bangladesh and Myanmar in the Bay of Bengal (Bangladesh/ Myanmar) and the 7 July 2014 Award of the Arbitral Tribunal in the Bay of Bengal Maritime Boundary Arbitration Between Bangladesh and India; ${ }^{33}$ to suppress maritime terrorism and unlawful acts against the safety of maritime

$30 \quad$ For a functional cooperative solution to this problem, see Raghavendra Mishra, The "Grey Area" in the Northern Bay of Bengal: A Note on a Functional Cooperative Solution, 47 OCEAN DeVElopment \& International LaW 29 (2016). (DRAFT) (2018), https://mofa.portal.gov.bd/sites/default/files/files/mofa.portal.gov.bd/ page/6aac4oc8_cdc3_4418_8755_db68foec9d5a/Bangladesh\%2oMaritime\%20Zone\%20 Act $\% 202018 \% 20$ Draft.pdf.

$32 \quad I d$. at 2.

33 Id. 
navigation and to provide for matters connected therewith or incidental thereto'; ${ }^{34}$ and 'to guide on international law applicable to armed conflicts at sea and to give conscious effect of the intrinsic, ecological, social, economic, scientific, educational, values of ocean governance, armed conflicts at sea and its components and protection of marine environment.' ${ }^{35}$

\section{5 Climate Change and Its Possible Effect on Bangladesh}

Bangladesh as a member of the global south has been facing the consequences of international law and its norms facilitating the developed countries. In this post-colonial era, the international environmental laws are still in the nature of soft law lacking binding mechanisms. However, the global south is continuously trying to influence international law-making, even though in the nature of soft laws in the field of environmental law. This shall ultimately result in the creation of some globally accepted norms. ${ }^{36}$

Even in this global trend of ignoring international law mandates, Bangladesh is a party to the United Nations Framework Convention on Climate Change 1992, Kyoto Protocol 1997, and Montreal Protocol 1987, and has accepted both the London Amendment and Copenhagen Amendment. As domestic mechanisms, there is the Bangladesh Climate Change Strategy and Action Plan (BCCSAP) 2009 which functions by focusing on six specific strategic areas: food security, social protection and health; comprehensive disaster management; infrastructure; research and knowledge management; mitigation and low carbon development; and capacity building and institutional strengthening. Bangladesh has also enacted the Climate Change Trust Fund Act in 2000 which has a close connection with вCCSAP. ${ }^{37}$ Another domestic instrument dealing with issues of climate change is the Financial Guideline of Government Projects under Climate Change Trust Fund Act, 2000. As a result of climate change, Bangladesh is vulnerable to sea level rise as well as to the melting of polar ice. The impact of climate change on Bangladesh is multifaceted. The consequences would range from an adverse effect on the availability and quality of water

\footnotetext{
$34 \quad I d$.

35 Id.

36 For a detailed discussion on the role of global south in the development of international environmental law, see Parvez Hassan, Role of the South in the Development of International Environmental Law, 1 Chinese Journal of Environmental LAW 133 (2017).

37 See Ministry of Env't \& Forests, Notification (2016) (Bangl.), http://www.dpp .gov.bd/upload_file/gazettes/15741_60576.pdf (stating the objectives of this Act in the preamble as establishing a trust fund for fighting against the climate change impacts).
} 
indirectly leading to an adverse effect on the livestock, to natural disasters leading to human health crises in the form of infectious diseases following such calamities. Bangladesh frequently faces natural disasters like flood, drought, cyclones, and storm surges; an inevitable impact of climate change will be more frequent, severe and intense natural disasters. Another impact that climate change will have is on the ecosystem and biodiversity, and the water as well as fisheries resources and crop agriculture among others, within the territory of the country.

The Patents, Designs and Trademarks Act of 1883 is the earliest legislation relating to intellectual property in Bangladesh. The Act was repealed. The new Patents and Designs Act was enacted in 1911 and the Trademarks Act in 1940. Both Acts were amended and the Department of Patents, Designs and Trademarks (DPDT) was formed under the Ministry of Industries in 2003. The Trademarks Ordinance was promulgated in 2008 and later in 2009, the Trademark Act was enacted. The Copyright Act, 2000 was enacted in 2000 and was amended in 2005. In 1991 Bangladesh became a member of the Paris Convention for the Protection of Industrial Property. The new regime for trademarks was established in 2009 as a requirement of compliance with the Paris Convention. This paved the way for Bangladesh to discharge some of its obligations under the Wто Agreement on Trade-Related Aspects of Intellectual Property Rights (TRIPS). ${ }^{38}$

Bangladesh is a signatory of TRIPS. TRIPS has created both prospects and challenges for Bangladesh in numerous fields. ${ }^{39}$ With its blessing, Bangladesh is able to create niche markets for geographically indicative goods like Jamdani or Hilsha Fish, Fazli Mango, traditional medicinal plants like Turmeric and Neem. However, it is presumed by experts that TRIPS would leave the farmers with limited rights to sell or exchange seeds on non-commercial basis. ${ }^{40}$

38 For a critical repercussion on this issue, see Muhammad A. Sayeed, Revisiting the Regime of Trademark Protection in Bangladesh: TRIPS Compatibility and Ramifications, 7 AsIAN JOURNAL OF INTERNATIONAL LAW 264 (2017).

See Mohammad Towhidul Islam, TRIPS Agreement of the WTO: ImplicaTiONS AND ChALlENGES FOR BANGladesh (1st ed. 2013) (discussing the implications and challenges of Bangladesh with regard to the TRIPS agreement).

40 See Mohammad Towhidul Islam, The Legal Regime of Plant Varieties and Farmers' Rights Protection in Bangladesh: Options and Challenges, 29 DhAKA UnIVERsity LAW JournaL (2018) (discussing the legal regime of farmer's rights protection in Bangladesh). 
Moreover, the issues of health and pharmaceutical industry in the IP rights regime are of particular concern in these days. ${ }^{41}$

In the absence of a universal policy regime for the protection of Cross-Border Geographical Indication, countries like Bangladesh are facing serious consequences in their trade interests. ${ }^{42}$ Bangladesh has enacted the Geographical Indication of Goods (Registration and Protection) Act 2013.43 It obtained the Geographical Indication (GI) registration on Dhakai Jamdani and Hilsha of Bangladesh. It has applied for 29 more items for GI registration like Katari Bhog rice and Fazli Mango. Very recently Bangladesh has got the Geographical Indication certificate of Khirsapat mango of Chapainawabganj as the third GI product of the country after Jamdani and Hilsha fish. The Department of Patents, Designs and Trademarks has already published a journal relating to the product. The concerned law requires such publication before issuing a GI certificate. Experts are of the opinion that in order to improve the intellectual property rights enforcement system, the government must focus on creating a special unit of law enforcement agencies and appoint special judges in order to resolve IP disputes.

\section{$7 \quad$ Human Rights Treaties and Bangladesh}

Both the UN Charter and the International Bill of Rights (comprising the UDHR, ICCPR and the ICESCR) deeply influenced the drafting of the Constitution of Bangladesh. Apart from its constitutional obligations regarding human rights, Bangladesh incurs obligations under international human rights law with regard to human rights as Bangladesh is a party to major international human rights treaties. For example, Bangladesh acceded to the International Covenant on Civil and Political Rights (ICCPR) in 2000, the International Covenant on Economic, Social and Cultural Rights (ICESCR) in 1998, the United Nations Convention on Cruel, Inhuman and Degrading Treatment and

41 See Mustafizur Rahman \& Sherajum Monira Farin, Research Report 2: WTO Decision on TRIPS and Public Health: A Window of Opportunity for Bangladesh's Pharmaceutical Industry, Centre for Policy Dialogue (2018), https://cpd.org.bd/wp-content/ uploads/2018/08/Research-Report-2-Rahman-and-Farin-2018_WTO-Decision-on-TRIPS-andPublic-Health.pdf (discussing the relevance of TRIPS in pharmaceutical industry).

42 See Mohammad Towhidul Islam \& Masrur Ansari, Cross-Border GI Protection: Challenges and Ramifications for Bangladesh, WIPO-WTO ColloQuium PAPERs (2017).

43 See Mohammad Towhidul Islam \& Md. Habib, Introducing Geographical Indications in Bangladesh, 24 Dhaka University LaW Journal $5^{1}$ (2016) (discussing the pros and cons of the GI regime of Bangladesh); see also id. 
Punishment (CAT) in 1998, the Convention on the Rights of the Child 1989 (CRC) in 1990, the International Convention on the Protection of the Rights of All Migrant Workers and Members of Their Families in 2011, the Convention on the Rights of Persons with Disabilities in 2007 and the Convention on the Elimination of All Forms of Discrimination Against Women (CEDAW) in 1984, and therefore it has obligations to implement the rights recognized in those treaties. Apart from treaties and conventions, customary international law also acts as a significant source of human rights obligations for Bangladesh.

As Bangladesh is a dualist country, treaties are not self-executing in Bangladesh. ${ }^{44}$ Ratification or accession to international treaties does not oblige the Government of Bangladesh under its domestic law to perform the obligations arising out of those treaties ${ }^{45}$ until they are incorporated into the domestic legal system of Bangladesh. Thus the state remains responsible only under international law, until the treaty provisions are transformed into its domestic law.

Nevertheless, the courts in Bangladesh at different times have applied different treaty provisions in interpreting constitutional human rights. The Appellate Division of the Supreme Court of Bangladesh observed in 2001 that although the Courts were not under an obligation to apply provisions of international law, they were not barred from applying the provisions of international law provided there was no conflict with domestic laws. ${ }^{46}$ There is a growing tendency of the Supreme Court of Bangladesh to apply different principles of international human rights law in deciding different cases in Bangladesh, which sometimes seems to be a step towards 'creeping monism' through judicial activism. ${ }^{47}$

The last few years as a phase has been significant for Bangladesh as it has submitted its initial reports which were overdue for more than a decade under

44 See Sumaiya Khair, Bringing International Human Rights Law Home: Trends and Practices of Bangladesh Courts, 17 Asian Yearbook of International LaW 47, $5^{2}$ (2011).

45 See Sheikh Hafizur Rahman Karzon \& Abdullah-Al Faruque, Status of International Law Under the Constitution of Bangladesh: An Appraisal, 3 BANGLAdesh Journal of LAW 23, 26 (1999).

46 Hussain Muhammad Ershad v. Bangl. and others, 21 BLD (2001) 69.

47 There is a series of case laws supporting this contention. See, e.g., Prof. Nurul Islam v. Gov't of Bangl., 52 DLR (2000) 413 (applying the combined effect of national and international law in the enforcement of human rights to ban and control advertisements promoting the use of tobacco); id. (observing that the Courts should not straightaway forget the obligations of the state under the international law); Bangl. Nat'l Women Lawyers Ass'n v. Gov't of Bangl., et al., 29 BLD (HCD) (2009) 415 (observing that in the absence of domestic laws and principles, the international covenants and treaties signed by the state are to be read into the fundamental rights of the constitution). 
the ICCPR and ICESCR. Bangladesh submitted its Initial Report under article 40 of the ICCPR to the Human Rights Committee in 2015, which was due in 2001. Again, it has submitted the Initial Report under articles 16 and 17 of the ICESCR to the Committee on Economic, Social and Cultural Rights in 2017, which was due in 200o. Bangladesh has furthermore submitted its initial state report in July 2019 to the Committee against Torture after a lengthy delay of 20 years from the accession to the UN Convention against Torture and Other Cruel, Inhuman or Degrading Treatment or Punishment, 1984. By submitting its overdue state reports, Bangladesh is increasingly taking steps to fulfil its obligations under international human rights law. 